\title{
Biocontrol of the sugarcane rootstalk borer, Diaprepes abbreviatus (L.) (Coleoptera: Curculionidae), with entomophilic nematodes'
}

\author{
Wilfredo Figueroa" and Jessé Román
}

\begin{abstract}
Eight greenhouse trials evaluated the efficacy of three species of entomophilic nematodes of the genus Steinernema ( $=$ Neoaplectana) in controlling neonate and 6-, 10-, and 14-week-old larvae of the sugarcane rootstalk borer (SRB), Diaprepes abbreviatus (L.), in sugarcane. Different densities of the nematodes Steinernema feltiae Filipjev, S. glaseri Steiner, and S. bibionis Bobien were tested. The infective nematodes controlled the 6- to 14-week-old $(0.64$ to $2.54 \mathrm{~cm})$ larvae. Significant results were also observed on the control of the effect of the larvae on sugarcane in the various parameters measured. No significant effects were observed with neonate (first instar) larvae. Larval mortality increased with age. Eightyfive percent mortality of 10-week-old grubs was observed at 240,000 nematodes per $1.8 \mathrm{~kg}$ of soil with a surface area of $0.02 \mathrm{~m} .^{2}$ Control of 10-week-old grubs was also possible at 480,000 nematodes per $3.6 \mathrm{~kg}$ of soil with a surface area of $0.03 \mathrm{~m}^{2}$ Fourteen-week-old grubs were the most susceptible to the attack of $S$. feltiae. S. glaseri is more effective than $S$. bibionis in controlling the grubs, but the effect of S. glaseri on the grubs is less consistent than that of $S$. feltiae. The three species of Steinernema performed well at temperatures of $20^{\circ}$ to $31^{\circ} \mathrm{C}$.
\end{abstract}

\section{RESUMEN}

Nematodos entomofílicos para controlar el gorgojo barrenador de la raíz de la caña de azúcar, Diaprepes abbreviatus

Se hicieron ocho experimentos de invernadero con caña de azúcar de 4 y 7 meses de germinada para determinar la susceptibilidad de las larvas (neonatas y de 6, 10 y 14 semanas de edad) de Diaprepes abbreviatus a los nematodos entomofílicos del género Steinernema. Se considera a Diaprepes como una plaga severa de la caña de azúcar en Puerto Rico y el Caribe. Se estudió la eficacia de diferentes densidades de las larvas infectivas de los nematodos Steinernema feltiae, S. glaseri y S. bibionis para controlar las larvas de $D$. abbreviatus y el efecto resultante en los siguientes ocho parámetros de la caña de azúcar: número de perforaciones del tallo subterráneo, número de plantas muertas, porcentaje de mortalidad de las larvas de D. abbreviatus, peso seco del follaje y del tallo, altura de la caña, peso seco de las raíces, número de retoños vivos y número de retoños muertos. Los nematodos fueron eficaces para combatir las larvas del insecto de 6 a 14 semanas de edad, y afectaron significativamente varios de los parámetros estudiados. No hubo efecto significativo en la mortalidad de las larvas neonatas. La mortalidad de las

'Manuscript submitted to Editorial Board 11 September 1989.

${ }^{2}$ Assistant Nematologist, Department of Crop Protection.

${ }^{3}$ Nematologist, Department of Crop Protection. 
larvas aumentó con la edad; las de 10 a 14 semanas fueron más susceptibles. Hubo un $85 \%$ de mortalidad en larvas de 6 semanas de edad al someterlas a 240,000 nematodos 5 . feltiae por $1.8 \mathrm{~kg}$. de suelo. La mortalidad máxima observada para larvas de 10 semanas de edad fue de un $95 \%$ al someterlas a 480,000 nematodos por $3.6 \mathrm{~kg}$. de suelo. De 14 a 16 semanas parece ser la edad en que las larvas de $D$. abbreviatus son más susceptibles a $S$. feltiae, pues todas las densidades de nematodos que se usaron contra las larvas del insecto causaron de 70 a $80 \%$ de mortalidad. 5. glaseri y S. bibionis fueron menos eficaces que $S$. feltiae para las mismas densidades. S. glaseri fue más eficaz que S. bibionis. Hubo un buen comportamiento e infectividad de los nematodos a temperaturas de invernadero de 20 a $31^{\circ} \mathrm{C}$.

\section{INTRODUCTION}

The sugarcane rootstalk borer (SRB), Diaprepes abbreviatus (L.), occurs throughout the Caribbean basin and is one of the most important pests of sugarcane and other economically important crops $(1,3,9,12,13,22)$. The adult weevil known as "vaquita" has a life cycle of 1 to 2 years and is abundant on the north and south coasts of Puerto Rico.

The larval stage of the weevil attacks the underground portions of the stem whereas the adult feeds on the foliage of plants. Attacks of this insect have also been reported in fruit trees, grasses, bananas, plantains, ornamental plants, forest trees, starchy crops and vegetables $(11,26,27)$. According to Wolcott (28), D. abbreviatus is the worst pest of sugarcane in Puerto Rico and the West Indies. Damage caused by this insect in Puerto Rico in $1977-78$ was estimated at $\$ 27.7$ million on 70,000 acres with $46 \%$ of the sugarcane infested (8). In Florida it is considered a potential threat to the citrus industry $(3,4,5)$.

Since the banning of insecticide Aldrin in 1973 by the Environmental Protection Agency (EPA) and after many trials with new products, no highly effective chemical has been found against this pest $(8,21)$. As a consequence, increasing populations of this and other soil insects have been observed (8).

A potential alternative is the biological control of SRB with entomophilic nematodes. Their efficacy has been demonstrated in previous tests against a wide host range, including soil-inhabiting and stem-boring insects $(4,6,7,8,14,15,17,18,19,20,23,24)$.

\section{MATERIALS AND METHODS}

The first four experiments were conducted with 4-month-old sugarcane plants, whereas in experiments 5 to 8, 7-month-old plants were used. In both cases the plants were germinated from 10-cm stem cuttings of the sugarcane variety PR 67-1070. All trials were arranged in a splitplot design. Infective juveniles of Steinernema feltiae, S. bibionis, and $S$. glaser $i$ were applied at four population densities (sub-treatments) replicated five times. Nematodes were supplied by Biosys, Palo Alto, CA. Neonate or first instar larvae and 6-, 10-, and 14-week-old SRB grubs 
were used. For experiments 1 to 4 , pots $15-\mathrm{cm}$ in diameter were filled with $1.8 \mathrm{~kg}$ (surface area of $0.02 \mathrm{~m}^{2}$ ) of a steam sterilized soil-sand mixture (3:1). Each of the three Steinermema species was applied at rates of $2,400,24,000$, and 240,000 infective juveniles in $20 \mathrm{ml}$ distilled water, poured equally around 45 potted plants. Fifteen pots which received 20 $\mathrm{ml}$ of water served as a control.

For experiments 5 to 8 , plastic pots $20 \mathrm{~cm}$ in diameter filled with 3.6 $\mathrm{kg}$ (surface area of $0.03 \mathrm{~m}^{2}$ ) of the same soil-sand mixture were used and nematodes applied at rates of $24,000,48,000$, and 480,000 infective juveniles. These nematode rates were equivalent to $0.25,2.5$, and 25 million nematodes per $\mathrm{m}^{2}$ of soil. Grubs were reared from field-collected adult weevils placed in $30 \times 38 \times 62 \mathrm{~cm}$ wire cages. Cabbage heads were supplied as food for the adults. For ovipositing, double strips of wax paper $2.5 \times 25.4 \mathrm{~cm}$ were hung in the upper inside of the cages. Eggs collected were superficially sterilized by immersion in $0.001 \%$ mercuric chloride for 3 minutes, $70 \%$ ethanol for 2 minutes, washed twice for 3 minutes in distilled water, and placed to hatch in $190-\mathrm{cm}^{3}$ plastic containers at 80 to $90 \%$ relative humidity. Hatched larvae were reared in plastic pots $\left(18.9 \mathrm{~L}^{3}\right)$ filled with a sterilized soil-sand mixture (1:3). Potato tubers were supplied as food for the grubs.

Temperature recorded during the course of the experiments ranged from $20^{\circ}$ to $31^{\circ} \mathrm{C}$. In all trials the grubs were introduced into each pot 24 hours after nematode inoculation. Soil $\mathrm{pH}$ was 7.2 .

In the first four tests the parameters measured were number of bores per rootstalk, number of dead plants and gxub mortality. In tests 5 to 8 the variables measured were dry weight of foliage and stem, height of cane at nematode inoculation and harvest time, dry weight of roots, number of bores per rootstalk, number of live shoots, number of dead shoots, percentage of larval and plant mortality.

The sowing of the sugarcane and the rearing of the grubs were timed in order to have the appropriate age of cane and grubs at the beginning

TABLE 1.-Effectiveness of three species of Steinernema in controlling 100 neonate Diaprepes abbreviatus lamae on sugarcane. (Experiment 1)

\begin{tabular}{clcc}
\hline \multirow{2}{*}{$\begin{array}{c}\text { Treatment } \\
\text { (Nematodes per } \\
1.8 \mathrm{~kg} \text { of soil) }\end{array}$} & \multicolumn{3}{c}{$\begin{array}{c}\text { Number of borings in the } \\
\text { underground stem }\end{array}$} \\
\cline { 2 - 4 } & S. feltiae & S. glaseri & S. bibionis \\
\hline 2,400 & $1.0 \mathrm{ab}$ & $0.2 \mathrm{a}$ & $0.8 \mathrm{ab}$ \\
24,000 & $0.6 \mathrm{ab}$ & $0.4 \mathrm{a}$ & $0.8 \mathrm{ab}$ \\
240,000 & $0.2 \mathrm{~b}$ & $0.4 \mathrm{a}$ & $0.0 \mathrm{~b}$ \\
Control & $1.2 \mathrm{a}$ & $1.0 \mathrm{a}$ & $1.0 \mathrm{a}$ \\
\hline
\end{tabular}

'In all tables, values in columns followed by a common letter do not differ significantly at $\mathrm{P}=0.05$ according to Duncan's multiple range test. 
TABLE 2.-Effectiveness of three species of Steinernema at different population levels in controlling 6-week-old Diaprepes abbreviatus grubs on sugarcane. (Experiment 2)

\begin{tabular}{cccc}
\hline $\begin{array}{c}\text { Treatment } \\
\text { (Nematodes per } \\
1.8 \mathrm{~kg} \text { of soil) }\end{array}$ & \multicolumn{3}{c}{ Grub mortality (\%) } \\
\cline { 2 - 4 } & S. felline & S.glaseri & S. bibionis \\
\hline 2,400 & $33.3 \mathrm{a}^{\mathrm{a}}$ & $13.3 \mathrm{ab}$ & $13.3 \mathrm{a}$ \\
24,000 & $40.0 \mathrm{a}$ & $40.0 \mathrm{~b}$ & $20.0 \mathrm{a}$ \\
240,000 & $93.3 \mathrm{~b}$ & $40.0 \mathrm{~b}$ & $20.0 \mathrm{a}$ \\
Control & $26.7 \mathrm{a}$ & $6.0 \mathrm{a}$ & $20.0 \mathrm{a}$ \\
\hline
\end{tabular}

'See table 1.

of each experiment. Plants were watered periodically to maintain a moderate soil moisture of approximately 50 to $60 \%$ field capacity.

In experiments 5 to 8 the soil and nematodes were twice the amounts as those in tests 1 to 4 .

\section{RESULTS}

The following tables present only those parameters where significant differences were obtained. Table 1 presents information of experiment 1 with neonate or first instar larvae. S. feltiae and $S$. bibionis, effective when evaluated by the bored underground stem method, showed significant results at 240,000 nematodes $/ 1.8 \mathrm{~kg}$ of soil.

In experiment 2 (table 2) 6-week-old ( $0.64 \mathrm{~cm}$ approx.) grubs were evaluated. Nematode treatments at densities of $240,000 \mathrm{~S}$. feltiae, 24,000 and $240,000 \mathrm{~S}$. glaseri caused significant grub mortality.

In experiment 3 (table 3 ) 10-week-old (1.27 cm approx.) larvae were used. Significant differences in grub mortality were observed for the middle and high $S$. feltiae dosages. Also S. glaseri at 240,000 infective juveniles provided effective grub control.

Table 4 summarizes information of experiment 4 with 14-week-old $(1.90$ to $2.54 \mathrm{~cm})$ grubs. S. feltiae caused significant gxub mortality at the 240,000 nematode density and reduced the number of dead plants, when compared with the 24,000 density.

TABLE 3.-Effectiveness of three species of Steinernema al different population levels in controlling 10-week-old Diaprepes abbreviatus grubs on sugarcane. (Experiment 3)

\begin{tabular}{cccc}
\hline \multirow{2}{*}{$\begin{array}{c}\text { Treatment } \\
\text { (Nematodes per } \\
1.8 \mathrm{~kg} \text { of soil) }\end{array}$} & \multicolumn{3}{c}{ Grub mortality (\%) } \\
\cline { 2 - 4 } 2,400 & S. feltiae & S. glaseri & S. bibionis \\
\hline 24,000 & $13.3 \mathrm{~b}^{1}$ & $6.7 \mathrm{~b}$ & $20.0 \mathrm{a}$ \\
240,000 & $53.3 \mathrm{a}$ & $40.0 \mathrm{ab}$ & $13.3 \mathrm{a}$ \\
Control & $66.7 \mathrm{a}$ & $53.3 \mathrm{a}$ & $33.3 \mathrm{a}$ \\
& $13.3 \mathrm{~b}$ & $13.3 \mathrm{~b}$ & $6.7 \mathrm{a}$ \\
\hline
\end{tabular}

'See table 1. 
TABLE 4.-Effectiveness of three species of Steinernema at differenl population densities in controlling 14-week-old Diaprepes abbreviatus grubs on sugarcane. (Experiment 4)

\begin{tabular}{|c|c|c|c|c|c|c|}
\hline \multirow{2}{*}{$\begin{array}{l}\text { Treatments } \\
\text { (Nematodes per } \\
1.8 \mathrm{~kg} \text { of soil) }\end{array}$} & \multicolumn{3}{|c|}{ Grub mortality (\%) } & \multicolumn{3}{|c|}{ Number of dead plants } \\
\hline & S. feltiae & S. glaseri & S. bibionis & S. felliae & S. glaseri & S. bibionis \\
\hline 2,400 & $33.3 b^{\prime}$ & $20.0 \mathrm{a}$ & $26.7 \mathrm{a}$ & $0.4 \mathrm{ab}$ & $0.6 \mathrm{a}$ & $0.2 \mathrm{a}$ \\
\hline 24,000 & $33.3 \mathrm{~b}$ & $33.3 \mathrm{a}$ & $13.3 \mathrm{a}$ & $0.8 a$ & $0.6 \mathrm{a}$ & $0.2 \mathrm{a}$ \\
\hline 240,000 & $86.7 a$ & $53.3 \mathrm{a}$ & $20.0 \mathrm{a}$ & $0.2 \mathrm{~b}$ & $0.4 \mathrm{a}$ & $0.4 \mathrm{a}$ \\
\hline Control & $13.3 \mathrm{~b}$ & $20.0 \mathrm{a}$ & $13.3 \mathrm{a}$ & $0.0 \mathrm{~b}$ & $0.6 \mathrm{a}$ & $0.6 \mathrm{a}$ \\
\hline
\end{tabular}

'See table 1.

In trial 5 (table 5) S. feltiae at rates of 4,800 and 48,000 and S. glaseri at 48,000 infective nematodes were significantly effective when evaluated by the live shoots method. All $S$. feltiae treatments significantly diminished the number of dead shoots.

Experiment 6 was conducted with 6-week-old larvae (table 6). The 48,000 and the 480,000 densities of $S$. feltiae and S. bibionis significantly reduced the number of borings in the rootstalk. Also the same densities of $S$. feltiae and the $48,000 \mathrm{~S}$. glaseri and S. bibionis caused significant larval mortality.

TABLE 5.-Evaluation of the efficacy of three population levels of Steinernema spp. in controlling first instar larvae of D. abbreviatus on two parameters of sugarcane.

(Experiment 5)

\begin{tabular}{cccccccc}
\hline $\begin{array}{c}\text { Treatments } \\
\text { (Nematodes per } \\
3.6 \text { kg of soil) }\end{array}$ & \multicolumn{3}{c}{ Live shoots } & & \multicolumn{3}{c}{ Dead shoots } \\
\cline { 2 - 4 } \cline { 6 - 8 } & S. feltiae & S. glaseri & S. bibionis & & S. feltiae & S. glaseri & S. bibionis \\
\hline 4,800 & $0.6 \mathrm{a}$ & $0.0 \mathrm{~b}$ & $0.2 \mathrm{a}$ & & $0.2 \mathrm{~b}$ & $0.4 \mathrm{a}$ & $1.2 \mathrm{a}$ \\
48,000 & $0.4 \mathrm{a}$ & $0.4 \mathrm{a}$ & $0.4 \mathrm{a}$ & & $0.6 \mathrm{~b}$ & $0.0 \mathrm{a}$ & $0.0 \mathrm{~b}$ \\
480,000 & $0.2 \mathrm{~b}$ & $0.0 \mathrm{~b}$ & $0.2 \mathrm{a}$ & & $0.0 \mathrm{~b}$ & $0.2 \mathrm{a}$ & $0.4 \mathrm{~b}$ \\
Control & $0.0 \mathrm{~b}$ & $0.0 \mathrm{~b}$ & $0.2 \mathrm{a}$ & & $1.4 \mathrm{a}$ & $0.4 \mathrm{a}$ & $0.4 \mathrm{~b}$ \\
\hline
\end{tabular}

'See table 1.

TABLE 6.-Evaluation of the efficacy of three population levels of Steinernema spp. in controlling 6-week-old lavvae of D. abbreviatus on two parameters of sugarcane.

(Experiment 6)

\begin{tabular}{|c|c|c|c|c|c|c|}
\hline \multirow{2}{*}{$\begin{array}{l}\text { Subtreatments } \\
\text { (Nematode per } \\
3.6 \mathrm{~kg} \text { of soil) }\end{array}$} & \multicolumn{3}{|c|}{$\begin{array}{l}\text { Number of borings per } \\
\text { subterranean stem }\end{array}$} & \multicolumn{3}{|c|}{ Grub mortality (\%) } \\
\hline & S. feltiae & S. glaseri & S. bibionis & S. felliae & S. glaseri & S. bibionis \\
\hline 4,800 & $2.8 \mathrm{a}^{1}$ & $2.6 \mathrm{a}$ & $3.6 \mathrm{ab}$ & $50.0 \mathrm{~b}$ & $55.0 \mathrm{ab}$ & $40.0 \mathrm{~b}$ \\
\hline 48,000 & $1.0 \mathrm{~b}$ & $1.8 \mathrm{a}$ & $2.4 \mathrm{c}$ & $80.0 \mathrm{a}$ & $75.0 \mathrm{a}$ & $65.0 \mathrm{a}$ \\
\hline 480,000 & $0.8 b$ & $2.6 \mathrm{a}$ & $2.8 \mathrm{bc}$ & $85.0 \mathrm{a}$ & $70.1) \mathrm{ab}$ & $50.0 \mathrm{ab}$ \\
\hline Control & $2.2 \mathrm{a}$ & $2.0 \mathrm{a}$ & $4.0 \mathrm{a}$ & $50.0 \mathrm{~b}$ & $50.0 \mathrm{~b}$ & $40.0 \mathrm{~b}$ \\
\hline
\end{tabular}

${ }^{1}$ See table 1. 
TABLE 7.-Overall comparison of the efficacy of three species of Steinernema spp. in controlling 6-week-old larvae of $\mathrm{D}$. abbreviatus on two parameters of sugarcane.

(Experiment 6)

\begin{tabular}{lcc}
\hline $\begin{array}{l}\text { Treatment } \\
\text { (Nematode species) }\end{array}$ & $\begin{array}{c}\text { Grub mortality } \\
(\%)\end{array}$ & $\begin{array}{c}\text { Number of borings per } \\
\text { subterranean stem }\end{array}$ \\
\hline S. feltiae & $58.8 \mathrm{a}^{1}$ & $1.7 \mathrm{a}$ \\
S. glaseri & $62.5 \mathrm{a}$ & $2.3 \mathrm{ab}$ \\
S. bibionis & $48.9 \mathrm{~b}$ & $3.2 \mathrm{~b}$ \\
\hline
\end{tabular}

'See table 1.

A high mortality that we cannot attribute to any particular cause was observed for the three species of Steinernema at the control treatment. When an overall comparison of the efficacy of the three species was established (table 7) S. feltiae and S. glaseri caused higher larval mortality than $S$. bibionis. Also, $S$. feltiae was more effective than $S$. bibionis in reducing the number of borings in the rootstalk.

Tables 8 to 11 summarize results of experiment 7 with 10-week-old grubs. Plants were significantly higher and more grubs were killed at densities of 48,000 and $480,000 \mathrm{~S}$. feltiae (table 8). Also, at 480,000 nematodes, $S$. glaseri killed a significant number of grubs. A significant reduction of the number of borings in the rootstalk and higher values in weight of roots, foliage and stem were obtained with 48,000 and 480,000 S. feltiae nematodes (tables 9 and 10). S. glaseri at 480,000 reduced the number of borings in the rootstalk, and $S$. bibionis at the same density increased the dry weight of roots. S. feltiae and $S$. glaseri were more effective than $S$. bibionis in increasing plant height (table 11). In an overall comparison $S$. feltiae excelled $S$. glaseri and $S$. bibionis in larval mortality, dry weight of roots, number of borings in the rootstalk, and dead plants.

Experiment 8 was conducted with 14-week-old grubs. The three treatments with $S$. feltiae and $S$. glaseri at the 4,800 and 48,000 densities

TABLE 8.-Evaluation of the efficacy of three population levels of Steinernema spp. in controlling 10-week-old larvae of $\mathrm{D}$. abbrevilatus on two parameters of sugarcane.

(Experiment 7 )

\begin{tabular}{|c|c|c|c|c|c|c|}
\hline \multirow{2}{*}{$\begin{array}{c}\text { Subtreatments } \\
\text { (Nematodes per } \\
3.6 \mathrm{~kg} \text { of soil) }\end{array}$} & \multicolumn{3}{|c|}{ Difference in height, $\mathrm{cm}$} & \multicolumn{3}{|c|}{ Grub mortality (\%) } \\
\hline & S. feltiae & S. glaseri & S. bibionis & S. feltiae & S. glaseri & S. bibionis \\
\hline 4,800 & $33.4 b^{\prime}$ & $28.4 \mathrm{a}$ & $24.2 \mathrm{a}$ & $40.0 \mathrm{~b}$ & $30.0 \mathrm{~b}$ & $35.0 \mathrm{a}$ \\
\hline 48,000 & $45.2 \mathrm{a}$ & $30.4 \mathrm{a}$ & $26.6 \mathrm{a}$ & $85.0 \mathrm{a}$ & $20.0 \mathrm{~b}$ & $50.0 \mathrm{a}$ \\
\hline 480,000 & $55.0 \mathrm{a}$ & $38.6 \mathrm{a}$ & $25.6 \mathrm{a}$ & $95.0 \mathrm{a}$ & $70.0 \mathrm{a}$ & $45.0 \mathrm{a}$ \\
\hline Control & $25.6 \mathrm{~b}$ & $33.0 \mathrm{a}$ & $25.6 \mathrm{a}$ & $40.0 \mathrm{~b}$ & $20.0 \mathrm{~b}$ & $25.0 \mathrm{a}$ \\
\hline
\end{tabular}

${ }^{\perp}$ See table 1. 
TABLE 9.-Evaluation of the efficacy of three population levels of Steinernema spp. in controlling 10-week-old larvae of $\mathrm{D}$. abbreviatus on two parometers of sugarcane. (Experiment 7)

\begin{tabular}{cccc}
\hline \multirow{2}{*}{$\begin{array}{c}\text { Subtreatments } \\
\text { (Nematodes per } \\
3.6 \mathrm{~kg} \text { of soil) }\end{array}$} & \multicolumn{3}{c}{$\begin{array}{c}\text { Number of borings per } \\
\text { subterranean stem }\end{array}$} \\
\cline { 2 - 4 } & S. feltiae & S. glaseri & S. bibionis \\
\hline 4,800 & $2.4 \mathrm{~b}^{\prime}$ & $2.8 \mathrm{~b}$ & $3.6 \mathrm{a}$ \\
48,000 & $0.6 \mathrm{a}$ & $4.0 \mathrm{~b}$ & $3.4 \mathrm{a}$ \\
480,000 & $0.0 \mathrm{a}$ & $2.0 \mathrm{a}$ & $3.0 \mathrm{a}$ \\
Control & $3.0 \mathrm{~b}$ & $3.6 \mathrm{~b}$ & $4.0 \mathrm{a}$ \\
\hline
\end{tabular}

'See table 1.

TABLE 10.-Evaluation of the efficacy of three population levels of Steinernema spp. in controlling 10-week-old larvae of $\mathrm{D}$. abbreviatus on two parameters of sugarcane (Experiment 7).

\begin{tabular}{|c|c|c|c|c|c|c|}
\hline \multirow{2}{*}{$\begin{array}{l}\text { Subtreatments } \\
\text { (Nematodes per } \\
3.6 \mathrm{~kg} \text { of soil) }\end{array}$} & \multicolumn{3}{|c|}{ Dry weight of roots, $g$} & \multicolumn{3}{|c|}{ Dry weight foliage and stem, $g$} \\
\hline & S. feltiae & S. glaseri & S. bibionis & S. feltiae & S. glaseri & S. bibionis \\
\hline 4,800 & $9.3 \mathrm{~b}^{1}$ & $10.9 \mathrm{a}$ & $8.3 b$ & $39.0 \mathrm{~b}$ & $54.6 \mathrm{a}$ & $38.7 \mathrm{a}$ \\
\hline 48,000 & $17.4 \mathrm{a}$ & $11.2 \mathrm{a}$ & $10.7 \mathrm{ab}$ & $71.6 \mathrm{a}$ & $51.3 \mathrm{a}$ & $50.0 \mathrm{a}$ \\
\hline 480,000 & $17.5 \mathrm{a}$ & $10.5 \mathrm{a}$ & $11.4 \mathrm{a}$ & $81.5 \mathrm{a}$ & $52.3 \mathrm{a}$ & $50.0 \mathrm{a}$ \\
\hline Control & $10.8 \mathrm{~b}$ & $8.9 a$ & $7.8 \mathrm{~b}$ & $44.3 \mathrm{~b}$ & $42.8 \mathrm{a}$ & $35.1 \mathrm{a}$ \\
\hline
\end{tabular}

'See table 1.

TABLE 11.-Overall comparison of the efficacy of three species of Steinernema spp. in controlling 10-zveek-old larvae of $\mathrm{D}$. abbreviatus on five parameters of sugarcane.

(Experiment 7)

\begin{tabular}{lccccc}
\hline $\begin{array}{l}\text { Treatment } \\
\text { (Nematode } \\
\text { species) }\end{array}$ & $\begin{array}{c}\text { Difference } \\
\text { in height }\end{array}$ & $\begin{array}{c}\text { Grub } \\
\text { mortality }\end{array}$ & $\begin{array}{c}\text { Number of } \\
\text { Dry weight } \\
\text { of roots }\end{array}$ & $\begin{array}{c}\text { subterngs per } \\
\text { stem }\end{array}$ & $\begin{array}{c}\text { Number } \\
\text { of dead } \\
\text { plants }\end{array}$ \\
\hline & $c m$ & $\%$ & $g$ & & \\
S. feltiae & $39.8 \mathrm{a}$ & $65.0 \mathrm{a}$ & $13.7 \mathrm{a}$ & $1.5 \mathrm{a}$ & $0.1 \mathrm{a}$ \\
S. glaseri & $32.6 \mathrm{a}$ & $35.0 \mathrm{~b}$ & $10.4 \mathrm{~b}$ & $3.3 \mathrm{~b}$ & $0.3 \mathrm{~b}$ \\
S. bibionis & $25.5 \mathrm{~b}$ & $38.8 \mathrm{~b}$ & $9.5 \mathrm{~b}$ & $3.5 \mathrm{~b}$ & $0.4 \mathrm{~b}$ \\
\hline
\end{tabular}

'See table 1.

caused significant grub mortality (table 12). Additionally, S. feltiae at the 480,000 nematode density, caused a higher value in dry weight of foliage and stem than in lower densities. A reduction of the number of borings in the rootstalk was obtained with $S$. feltiae at the middle and high dosages, and for all nematode treatments of $S$. bibionis (table 13). An overall comparison of the efficacy of the three nematode species (table 14) showed that $S$. feltiae and $S$. bibionis were significantly more effec- 
TABLE 12.-Evaluation of the efficacy of three population levels of Steinernema spp. in controlling 14-weet-old larvae of D. abbreviatus on two parameters of sugarcane.

(Experiment 8)

\begin{tabular}{|c|c|c|c|c|c|c|}
\hline \multirow{2}{*}{$\begin{array}{l}\text { Subtreatments } \\
\text { (Nematodes per } \\
3.6 \mathrm{~kg} \text { of soil) }\end{array}$} & \multicolumn{3}{|c|}{ Grub mortality $(\%), g$} & \multicolumn{3}{|c|}{ Dry weight of foliage and stem, $g$} \\
\hline & S. feltioe & S. glaseri & S. bibionis & S. felliae & S.glaseri & S. bibionis \\
\hline 4,800 & $70.0 \mathrm{a}^{1}$ & $55.0 \mathrm{a}$ & $35.0 \mathrm{a}$ & $38.6 \mathrm{~b}$ & $36.5 \mathrm{~b}$ & $57.5 \mathrm{a}$ \\
\hline 48,000 & $70.0 \mathrm{a}$ & $50.0 a$ & $40.0 \mathrm{a}$ & $45.8 \mathrm{~b}$ & $54.9 \mathrm{a}$ & $49.8 \mathrm{a}$ \\
\hline 480,000 & $80.0 \mathrm{a}$ & $35.0 \mathrm{ab}$ & $35.0 \mathrm{a}$ & $54.2 \mathrm{a}$ & $46.0 \mathrm{a}$ & $45.0 \mathrm{a}$ \\
\hline Control & $25.0 \mathrm{~b}$ & $15.0 \mathrm{~b}$ & $20.0 \mathrm{a}$ & $37.2 \mathrm{~b}$ & $51.2 \mathrm{a}$ & $51.0 \mathrm{a}$ \\
\hline
\end{tabular}

'See table 1.

TABLE 13.-Evaluation of the efficacy of three population levels of Steinernema spp. in. controlling 14-week-old larvae of $\mathrm{D}$. abbreviatus on one parameter of sugarcane. (Experiment 8)

\begin{tabular}{cccc}
\hline \multirow{2}{*}{$\begin{array}{c}\text { Subtreatments } \\
\text { (Nematodes per }\end{array}$} & \multicolumn{3}{c}{ Number of borings per subterranean stem } \\
\cline { 2 - 4 } 3.6 kg of soil) & S. feltiae & S. glaseri & S. bibionis \\
\hline 4,800 & $1.2 \mathrm{a}^{\mathrm{1}}$ & $0.2 \mathrm{a}$ & $1.6 \mathrm{a}$ \\
48,000 & $0.2 \mathrm{~b}$ & $0.0 \mathrm{a}$ & $1.4 \mathrm{a}$ \\
480,000 & $0.2 \mathrm{~b}$ & $0.4 \mathrm{a}$ & $1.8 \mathrm{a}$ \\
Control & $1.8 \mathrm{a}$ & $0.2 \mathrm{a}$ & $0.2 \mathrm{~b}$ \\
\hline
\end{tabular}

'See table 1.

tive in producing higher cane stems than S. glaseri. Also, S. feltiae caused greater larval mortality than $S$. glaseri and $S$. bibionis.

\section{DISCUSSION AND CONCLUSIONS}

At high densities $S$. glaseri and $S$. bibionis reduce the damage to the sugarcane rootstalk by SBR neonate or first instar larvae. Neonate larvae are less susceptible than older ones as evidenced by the low mortality caused by the three nematode species at all densities. First-instar larvae are very small ( $1 \mathrm{~mm}$ long $=1,000$ microns) and their points of entry might be too small for the penetration of the infective stages of the three Steinernema species, which are 547 to $1450 \mu \mathrm{m}$ long, and range from 24 to 34 microns in diameter $(2,10,16,29)$.

Also, the fast moving larvae might not be easily encountered by the nematodes since the newly hatched larvae do not penetrate immediately into the soil, but wander over it for a while (personal observations).

$S$. feltiae, S. glaseri, and S. bibionis are capable of causing significant mortality of 6-week-old SBR larvae. An increase in the densities of $S$. feltiae can increase mortality of 6-week-old grubs. S. glaseri and $S$. bibionis are effective in reducing the number of borings in the rootstalk. Many dead larvae were found within the bored tunnels. This fact was observed by Lindegreen et al. (11) when nematodes were applied to tunnels bored in fig trees by the carpenter worm Prionosystus robinae. 
TABLE 14.-Overall comparison of the efficacy of three species of Steinernema spp. in controlling 14-week-old D. abbreviatus larvae on two parameters of sugarcane. (Experiment 8)

\begin{tabular}{ccc}
\hline $\begin{array}{c}\text { Treatment } \\
\text { (Nematode species) }\end{array}$ & in height' & Grub mortality \\
\hline & & $(\%)$ \\
S. feltiae & $34.7 \mathrm{a}^{\mathrm{s}}$ & $61.3 \mathrm{a}$ \\
S. glaseri & $21.6 \mathrm{~b}$ & $38.8 \mathrm{~b}$ \\
S. bibionis & $25.5 \mathrm{a}$ & $32.5 \mathrm{~b}$ \\
\hline
\end{tabular}

'See table 1.

By destroying the insect larvae, S. feltiae can significantly affect the dry weight of the foliage and stem, dry weight of roots and number of borings in the rootstalk. S. glaseri at high rates causes significant mortality of the grubs. At the high density $S$. bibionis affects the dry weight of roots. Ten-week-old grubs, voracious when feeding on the rootstalk of sugarcane, cause considerable damage.

Grubs 14 weeks or older are susceptible to the effect of S. feltiae; all densities applied caused equal mortality. Even so, an increase from the $48,000(24,000)$ nematode rate to the $480,000(240,000)$ did not increase mortality significantly. Similar results on mortality were obtained in studies conducted by Román and Figueroa (18). Therefore, an increase of the density of $S$. feltiae increased the dry weight of the foliage and stem. S. glaseri can also control the 14-week-old larvae at the middle dosage. S. bibionis can significantly reduce the number of borings in the rootstalk.

Preliminary studies have shown that under conditions of high humidity, favorable temperature and viable cultures of the infective stage of the three Steinernema species, SRB grubs may be effectively controlled $(17,18)$. This study appears to be the first of its kind. Research should be continued for the practical application of these nematodes on many insect pests of economic importance in Puerto Rico's agriculture.

\section{LITERATURE CITED}

1. Barrow, . H., 1924. White grubs, Lachosterna spp. and larvae of the weevil root-borer, Diaprepes splengeri L. attacking sugarcane in the Guánica district of Puerto Rico, and methods practiced for controlling them. J. Dep. Agric. P. R. 8:22-6.

2. Beavers, B. J., 1982. Biology of Diaprepes abbreviatus (Coleoptera: Curculionidae) reared on artificial diet. Fla. Entomol. 65: 263-69.

3. - 1984. Susceptibility of Diaprepes abbreviatus to the parasitic nematode Steinernema glaseri. IRCS Med. Sci. 12: 480.

4. - P. T. McGobern and E. V. Adler, 1964. D. abbreviatus: laboratory and field behavioral and attractancy studies. Environ. Entomol. 11: 436-39.

5. _ C. W. McCoy and D. T. Kaplan, 1983. Natural enemies of subterranean Diaprepes abbreviatus (Coleoptera:Curculionidae) larvae in Florida. Environ. Entomol. 12: 840-43. 
6. Beeding, R. A. and A. L. Miller, 1981. Disinfecting black currant cuttings of Syanthedon tipuliformis using the insect parasitic nematode, Neoaplectana bibionis. Environ. Entomol. 10: 449-53.

7. Belair, G. and G. Boivin, 1985. Susceptibility of the carrot weevil (Coleoptera:Curculionidae) to Steinemema feltiae, S. bibionis and Heterorhabditis heliothidis. J. Nematol. 17: 363-66.

8. Estación Experimental Agricola, 1979. Caña de Azúcar. Informe Anual Univ. de P. R. p. 4.

9. FAO, 1969. Outbreak and new records. Plant Protection Bull. 17: 41-3.

10. Glaser, R. W., C. W. McCoy and H. B. Girth, 1940. The biology and economic importance of a nematode parasitic in insects. J. Parasitol. 26: 479-95.

11. Lindegreen, J. E., T. T. Yamashita and W. W. Barnett, 1981. Parasitic nematode may control carpenterworm in fig trees. Cal. Agric. 35: 25-6.

12. Martorell, L. F., 1945. A survey of the forest insects of Puerto Rico. J. Agric. Univ. P. R. 29: 457-61.

13. Mejia-Biaggi, F. and L. F. Martorell, 1976. Notes on the sugarcane soil insect pests in the Dominican Republic. Proc. of the 1973 meeting of the West Indies Sugar Technol., Barbados. 64: 278-82.

14. Petersen, J. J., 1981. Status and future of entomogenous nematodes. J. Nematol. 13: 239-40.

15. Poinar, G. O., Jr., 1966. Pathogenicity studies of neoaplectanid nematodes and their use for insect control. Ins, Pathol. and Microbiol. Cont. 6: 197-99.

16. — - 1967. Description and taxonomic position of the DD-136 nematode (Steinernematidae, Rhabditoidea) and its relationship to Neoaplectana carpocapsae Weiser. Proc. Helminthol. Soc. Wash. 34: 199-209.

17. —- J. Evans and E. Schuster, 1983. Field test of the entomogenous nematode Neoaplectana carpocapsae, for control of corn rootworm larvae (Diabrotica spp. Coleoptera), Prot. Ecol. 5: 337-42.

18. Román, J. and W. Figueroa, 1984. Control of the larva of the sugarcane weevil, Diaprepes abbreviatus L. with the entomogenous nematode Neoaplectana carpocapsae Weiser. J. Agric. Univ. P. R. 69: 153-58.

19. — - - and E. Abreu, 1984. Informe Anual Proyecto TAD-9 ante taller sobre picudos de las cítricas, Univ. Fla., Lake Alfred, Fla.

20. Schmiege, D. C., 1963. The feasibility of using a neoaplectanid nematode for control of some forest insect pests. J. Econ. Entomol. 56: 427-31.

21. Simanton, W. A. and R. C. Bullock, 1973. Evaluation of dip treatments to destroy Diaprepes abbreviatus on citrus nursery trees. F'la. Entomol. 56: 305-10.

22. Simmonds, F. J., 1953. Insect pests of sugarcane in the French Antilles. Trop. Agric. 30: $122-27$.

23. Triggiani, O. and G. O. Poinar, Jr., 1976. Infection of adult Lepidoptera by Neoaplectana carpocapsae (Nematoda). J. Invertebr. Pathol. 27: 413-14.

24. Wassink, H. and G. O. Poinar, Jr., 1984. Use of the entomogenous nematode Neoaplectana carpocapsae Weiser (Steinernematidae, Rhabditida) in Latin America. Nematropica 14: 97-109.

25. Wolcott, G. N., 1936. The life history of Diaprepes abbreviatus L. at Rio Piedras, P. R. J. Agric. Univ. P. R. 20: 883-914.

26. _- 1948. The insect pests of sugarcane. Manuscrito disponible Depto. de Protección de Cultivos, Estación Experimental Agrícola, Univ. P. R.

27. ——, 1948. The insects of Puerto Rico. J. Agric. Univ. P. R. 32: 90.

28. ——, 1951. Control of the soil-inhabiting grubs in Puerto Rico. J. Econ. Entomol. 44: 58-60.

29. Wouts, W. M., 1980. Biology, life cycle and redescription of Neoaplectana bibionis Bobien, 1937. (Nematoda:Steinernematoda). J. Nematol. 12: 62-72. 